\title{
Phase and Micro-Structural Characterization of Sanitary- Ware Fired at Different Temperature
}

\author{
ATHER HASSAN*, YASEEN IQBAL**, AND SYED ZAFAR ILYAS* \\ RECEIVED ON 01.04.2015 ACCEPTED ON 16.08.2016 \\ ABSTRACT
}

\begin{abstract}
The three main ingredients of sanitary-ware are clay, feldspar and quartz. This ware is being widely used and has therefore, attracted the attention of researchers from time to time. Consequently, it has been extensively investigated. The present study describes the phase and micro-structural analysis of sanitaryware samples collected from local (Durr Ceramics Peshawar) industry. XRD (X-Ray Diffraction) of samples fired at $1100^{\circ} \mathrm{C}$ reveals the presence of $\alpha$-quartz and primary mullite only. In addition to a-quartz and primary mullite, elongated needles of secondary mullite were also present in samples fired at 1200 and $1300^{\circ} \mathrm{C}$. Unlike typical vitreous ceramics bodies, regions containing elongated secondary mullite originating from the clay relict and growing into the feldspar relict were few in number which is consistent with the high clay content in the starting body ingredients of the investigated samples.
\end{abstract}

Another sample investigated for comparison purposes, contained all the phases mentioned above along with some corundum grains which indicated that the composition of sanitary ware varied from manufacturer to manufacturer. EDS (Energy Dispersive Spectroscopy) detected high concentration of Fe in some regions in the bulk but the glaze did not contain any $\mathrm{Fe}$.

Key Words: Clay, Flux, Mullite, Soda Glass, Filler.

\section{INTRODUCTION}

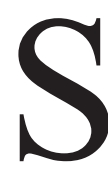
anitary-ware refers to the group of ceramics made from clay, flux and filler. The firing temperature of sanitary-ware is about $100-150^{\circ} \mathrm{C}$ lower than that of porcelain (Gragam [1]). Sanitaryware is in human use since centuries and has therefore, attracted the attention of many researchers from time to time.
The properties of materials are strongly dependent upon their processing conditions, constituent phases and microstructure, and the same is the case with sanitaryware. Therefore, the processing, phase and micro-structural evolution of vitreous ceramics including sanitary ware has been investigated previously (Klein, [2], Weymouth [3], Jackson [4], Cole [5] and Lee and Iqbal [6]).

* Department of Physics, Allama Iqbal Open University, Islamabad.

** Department of Physics, University of Peshawar, Peshawar.

Mehran University Research Journal of Engineering \& Technology, Volume 36, No. 3, July, 2017 [p-ISSN: 0254-7821, e-ISSN: 2413-7219] 


\section{MICROSTRUCTURE PROPERTY RELATIONSHIP OF SANITARY- WARE}

Sanitary-ware products are required to have minimum water absorption index, high scratch resistance, resistance to chemical detergents, crazing resistance, thermal shock resistance and maximum mechanical strength (Manfredini et. al. [7]). The manufacturers aim at producing good quality products and therefore, the researchers have continuously investigated the role of initial body ingredients, processing and their effect on the properties of finished products.

In sanitary-ware bodies, primary and secondary mullite crystallize from metakaolin $\left(\mathrm{Al}_{2} \mathrm{O}_{3}: 2 \mathrm{SiO}_{2}\right)$ coming from the de-hydroxylation of kaolinite and grow into the less viscous feldspar relict $\left(\mathrm{K}_{2} \mathrm{O} \cdot \mathrm{Al}_{2} \mathrm{O}_{3} \cdot 6 \mathrm{SiO}_{6}\right)$. McConville et. al. [8] reported that the Kaolin transformed to Meta-kaolin at $550^{\circ} \mathrm{C}$. However, Qiu et. al. [9] reported the formation of meta-kaolin by de-hydroxylation of Kaolinite at $420-660^{\circ} \mathrm{C}$.

$$
\mathrm{Al}_{2} \mathrm{O}_{3} \cdot 2 \mathrm{SiO}_{2} \cdot 2 \mathrm{H}_{2} \mathrm{O} \stackrel{\text { about } 420-660^{\circ} \mathrm{C}}{\longrightarrow} \mathrm{Al}_{2} \mathrm{O}_{3} \cdot 2 \mathrm{SiO}_{2}+2 \mathrm{H}_{2} \mathrm{O}
$$

At $980^{\circ} \mathrm{C}$, Mata-kaolin begins to decompose into $\mathrm{SiO}_{2}$ and $\gamma-\mathrm{Al}_{2} \mathrm{O}_{3}$ via

$$
\mathrm{Al}_{2} \mathrm{O}_{3} \cdot 2 \mathrm{SiO}_{2} \stackrel{\text { about } 980^{\circ} \mathrm{C}}{\longrightarrow} \gamma-\mathrm{Al}_{2} \mathrm{O}_{3}+2 \mathrm{SiO}_{2 \text { (amorphous) }}
$$

Amorphous silica produced during the decomposition of clay, re-combines with $\mathrm{Al}_{2} \mathrm{O}_{3}$ to form mullite at temperatures above $1100^{\circ} \mathrm{C}$ (Qiu et. al. [9]).

$3 \gamma-\mathrm{Al}_{2} \mathrm{O}_{3}+2 \mathrm{SiO}_{2 \text { (amorphous) }} \stackrel{\text { about } 1100^{\circ} \mathrm{C}}{\longrightarrow} 3 \mathrm{Al}_{2} \mathrm{O}_{3} \cdot 2 \mathrm{SiO}_{2}$

The $\mathrm{Al}_{2} \mathrm{O}_{3}: \mathrm{SiO}_{2}$ ratio in primary and secondary mullite has been reported to be 2:1 and 3:2 respectively (Iqbal and Lee [10]).

Various proportions of two types of feldspar are commonly used in the production of commercial white-ware bodies namely potash feldspar and soda feldspar (Schramm and
Hall [11]). The viscosity of the glassy phase in sodafeldspar containing porcelain bodies is less than that containing potash feldspar. The consequent increase in the fluidity of the melt accelerates the transformation of primary mullite into secondary mullite at high temperatures $\left(\geq 1200^{\circ} \mathrm{C}\right)$. Therefore, the type and proportion of initial body ingredients can be altered to improve the properties of the product (Schuller [12]).

At $1200^{\circ} \mathrm{C}$, the dissolution of $\alpha$-quartz speeds up and increases the quantity of liquid phase in the body. Pure clay relicts contain primary mullite $(\sim 7 \mathrm{~nm})$ and occasionally secondary mullite $(\sim 30 \mathrm{~nm})$ in clay relicts adjacent to large amount of feldspar relict at $1000^{\circ} \mathrm{C}$. Secondary mullite forms as a consequence of the diffusion process between feldspar and clay. It depends upon the diffusion of $\mathrm{K}_{2} \mathrm{O}$ and $\mathrm{Al}_{2} \mathrm{O}_{3}$. Feldspar melting point is lower than the other body ingredients so that the clay with high contents of feldspar possesses low viscosity. The clay relict agglomerates containing feldspar are more fluid than those without feldspar, so secondary mullites crystals grow larger in less viscous clay-feldspar mixture as compared to primary mullite in non-viscous feldspar-freeclay agglomerates (Iqbal and Lee [13]).

Systematic micro-structural investigation of tri-axial bodies of kaolin $\left\{\mathrm{Al}_{2} \mathrm{Si}_{2} \mathrm{O}_{5}(\mathrm{OH})_{4}\right\}$, feldspar $\left(\mathrm{K}_{2} \mathrm{O} \cdot \mathrm{Al}_{2} \mathrm{O}_{3} \cdot 0.6 \mathrm{SiO}_{2}\right.$, $\left.\mathrm{Na}_{2} \mathrm{O} . \mathrm{Al}_{2} \mathrm{O}_{3} .0 .6 \mathrm{SiO}_{2}, \mathrm{CaO} . \mathrm{Al}_{2} \mathrm{O}_{3} \cdot 0.2 \mathrm{SiO}_{2}\right)$, and quartz $\left(\mathrm{SiO}_{2}\right)$ reveals that Kaolin transforms to metakaolin at $550^{\circ} \mathrm{C}$, feldspar decomposes to meta-stable sanidine at temp > $600^{\circ} \mathrm{C}$ and begins to melts at e" $1000^{\circ} \mathrm{C}$ (Iqbal and Lee [13]).

Upon heating potash feldspar above $1200^{\circ} \mathrm{C}$, its melting point increases due to decomposition of orthoclase $\left(\mathrm{KAlSi}_{3} \mathrm{O}_{8}\right)$ into lucite $\left(\mathrm{KAlSi}_{2} \mathrm{O}_{6}\right)$ and silica-rich glass (Morey and Kumar, [14] cited in Schramm and Hall [11]).

Secondary mullite needles exist in a solution of cordierite crystals, rutile and $\alpha$-quartz instead of glassy phase in a 
mixture of crystallizing glass, clay and $\alpha$-quartz which increases the mechanical strength of porcelain bodies and improves their elasticity (Matti and Kumar [15]). Similarly glazed porcelains are stronger than unglazed bodies because glazing prevents propagation of microcracks on the surface of the body (Kobyashi et. al. [16]).

Mechanical properties of ceramics-ware can be improved by adding short fibers of alumina without any reaction with clay matrix (Palmonari et. al. [17]). The mechanical strength of sanitary-ware increases by addition of suitable ratio of soda glass (cullet) SG. SG melts at $720^{\circ} \mathrm{C}$ and results in the formation of maximum glassy phase at about $1100^{\circ} \mathrm{C}$, which increases verification, bulk density, and consequently decreases porosity and water absorption (Youssef et. al. [18]). Thus the moisture expansion of fired clay can be best controlled (Cole [5]).

Low porosity is necessary for good mechanical strength and resistance to moisture expansion. Porosity can cause glaze crazing and loss of strength. Long life of sanitaryware depends on porosity (Manfredini et. al. [7]).

According to Vaughan and Dinsdale[19].

$\mathrm{W}=\mathrm{k} \sqrt{\mathrm{t}}$

Where, $\mathrm{W}$ is volume expansion in time " $\mathrm{t}$ ", and $\mathrm{k}=10^{-8}$ g. $\mathrm{cm}^{-2} \mathrm{day}^{1 / 2}$ (sorption rate). For example, the recommended value of moisture expansion during one year for a sanitaryware product of internal area $0.5 \mathrm{~m}^{2}\left(5 \times 10^{3} \mathrm{~cm}^{2}\right)$ is $0.1 \% 0$.

The mixtures of mullite, silica and potash feldspar begins to melt at $985^{\circ} \mathrm{C}$. So the porosity of the white-ware bodies can be decreased by suitable ratio of the liquid $(9.5 \%$ $\mathrm{K}_{2} \mathrm{O}, 10.9 \% \mathrm{Al}_{2} \mathrm{O}_{3}, 79.8 \% \mathrm{SiO}_{2}$ ) and silica contents (Sallam et. al. [20]).

Important factor that influence the mechanical strength of the sanitary-ware, is the grain size of the filler such as $\alpha$-quartz. Cracks commonly observed in and around large quartz grains occur because of the large thermal expansion mismatch between the crystalline quartz $\left(\alpha \approx 23 \times 10^{-6} \mathrm{~K}^{-1}\right)$ and the glassy phase $\left(\alpha \approx 3 \times 10^{-6} \mathrm{~K}^{-1}\right)$ in the temperature range $20-750^{\circ} \mathrm{C}$ (Iqbal and Lee [13] cited in Lundin [21]). According to Knudsen relation (Knudsen [22] cited in Dinsdale and Wilkinson, [23]) quantitatively strength of the body is:

$\log \mathrm{S}=\mathrm{KD}^{-\mathrm{a}}$

Here $S$ and $D$ are strength and particle diameter and " $\mathrm{K}$ " and "a" are constants. This shows that the strength increases as the size decreases. However, as the grain size is reduced, a maximum strength is reached, beyond which further reduction in size is accompanied by a reduction in strength.

Coarse filler forms an unconnected dispersion with intervening smaller clay and flux particles. When flux particles melt, the area of contact between the glassy matrix and alumina particles increases, and the strength increases. When the filler size becomes very small, this situation no longer holds, as the filler may now be more in number to be connected (Dinsdale and Wilkinson, [23]).

The bending strength of porcelain can be increased by decreasing the size of $\alpha$-quartz particles to $10-30 \mu \mathrm{m}$ (Bradi [24]).

\section{EXPERIMENTAL PROCEDURE}

A local factory provided sanitary-ware samples. For XRD, powder (sieved $<325$ mesh) were scanned from $2 \theta=10^{\circ} \rightarrow$ $60^{\circ}$ at a scanning speed of $0.02 / \mathrm{min}$, using Geol diffractometer (with $\mathrm{CuK} \alpha$ radiation, $\lambda=0.154838 \mathrm{~nm}$ ) at $40 \mathrm{KV}$ and 20mA. JCPDS Cards 15-775 (mullite), 33-1161 (quartz), 09-0466 and 20-0554 (feldspar (albite)) and 191227 (sanidine) were used to identify crystal phases.

Scanning electron microscopy specimens were polished using 15 and $1 / 4 \mu \mathrm{m}$ diamond pastes after grinding with

Mehran University Research Journal of Engineering \& Technology, Volume 36, No. 3, July, 2017 [p-ISSN: 0254-7821, e-ISSN: 2413-7219] 
silicon carbide powder and water . The polished surfaces were etched for $3 \mathrm{~min}$ in 5\% HF solution and then gold/ carbon coated. A JEOL (JSM-5910) SEM equipped with X-Ray Energy Depressive Spectroscopy (EDX-INCA 200, Oxford Instruments, UK) of analysis range from Boron to Uranium and resolution of $130 \mathrm{eV}$, and SEI (Secondary Electron Images) detector, (Operating at 0.1-30 KV, resolution of $2.3 \mathrm{~nm}$ and magnification up to $300,000 \mathrm{X}$ ) was usedfor chemical analysis and morphology.

\section{RESULTS AND DISCUSSION}

\subsection{X-Ray Diffraction of Fired Samples}

XRD data for three samples fired at 1100 and $1300^{\circ} \mathrm{C}$, and one fired commercially, matched with standardized calculated data of the JCPDS cards revealed mainly mullite and $\alpha$-quartz phases for specified firing range. Additionally, XRD results for a sample collected from the industry (fired commercially) showed corundum phase.

The inter-planar spacings “d” corresponding to the major XRD peaks recorded for the sanitary-ware sample fired at $1100^{\circ} \mathrm{C}$ (Fig. 1) matched with the d-values for 15-775

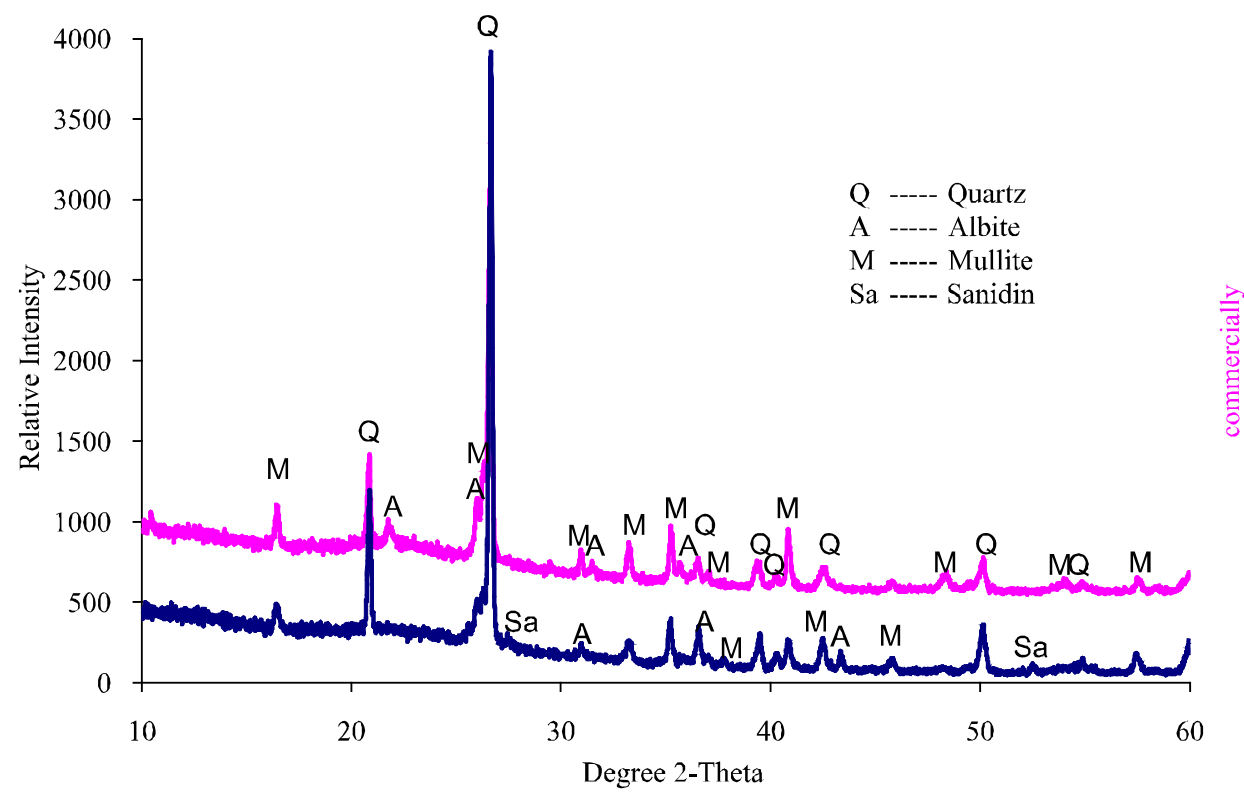

FIG. 1. COMPARISON OF XRD PATTERNS OF SANITARY-WARE SAMPLES FIRED COMMERCIALLY AND AT $1100^{\circ} \mathrm{C}$ (mullite), 33-1161 (quartz) and 09-0466 and 20-0554 (feldspar (albite)), however some of the minor peaks matched with the JCPDS cards for 19-1227 sanidine. Iqbal and Lee [13] reported formation of meta-stable sanidine in porcelain in temperature range $600-900^{\circ} \mathrm{C}$ beyond which it disappears, while in the mixed alkali feldspars, this temperature range extends from $900-1050^{\circ} \mathrm{C}$ (Mackenzie and Smith, [25]). So at $1100^{\circ} \mathrm{C}$, the presence of sanidine can be expected.

The X-ray peak positions and intensities observed for samples fired commercially and for the one fired at $1100^{\circ} \mathrm{C}$ (Fig. 1) are nearly the same, indicating that the firing temperature of the commercially fired sample lies in the range of $1050-1150^{\circ} \mathrm{C}$. Estimating on the basis of peak intensities for mullite, both the samples appeared to contain approximately similar amount of mullite. This suggests that the raw materials, composition and firing temperatures of the two bodies were nearly similar.

Fig. 2 shows a comparison of XRD traces observed for sanitary-ware samples fired at 1100 and $1300^{\circ} \mathrm{C}$ for two hours. Amorphous humps, although small, in the XRD 
pattern indicate the presence of amorphous material in the body. The decrease in the intensities of XRD peaks due to $\alpha$-quartz in the sample fired at $1300^{\circ} \mathrm{C}$ in comparison to the one fired at $1100^{\circ} \mathrm{C}$ indicates the beginning of dissolution of $\alpha$-quartz at temperatures $>1200^{\circ} \mathrm{C}$. At $1300^{\circ} \mathrm{C}$, the intensities of XRD peaks due to Mullite have increased, indicating an increase in the quantity of Mullite. Furthermore, peaks due to mullite are more pronounced and sharp in comparison to those observed for the sample fired at $1100^{\circ} \mathrm{C}$. This indicates that the mullite crystals have also grown in size consistent with the previous studies (Iqbal and Lee [13] and Dinsdale and Wilkinson, [23]).

Albite $\left(\mathrm{NaAl} \mathrm{Si}_{3} \mathrm{O}_{8}\right)$ phase is present due to the sodium feldspar present in the raw materials used and sanidine $(\mathrm{K}, \mathrm{Na})\left(\mathrm{Si}_{3} \mathrm{Al}\right) \mathrm{O}_{8}$ results from combination of Albite with potassium present in clay/feldspar.

Feldspar melts at $1100^{\circ} \mathrm{C}$ (Schramm and Hall, [11]) i.e. nepheline and sanidine have been reported to dissolve at temperature $<1100^{\circ} \mathrm{C}$ (Iqbal and Lee[13]), however, albite partially dissolves at temperature slightly above $1100^{\circ} \mathrm{C}$ (McConvile and Caspar [26]).
The current investigation of the microstructure has consistency with previous results in case of sanidine and albite. These two phases were present at $1100^{\circ} \mathrm{C}$. XRD at $1300^{\circ} \mathrm{C}$ (Fig. 2) also detected peaks of albite that indicated the presence of feldspar at high temperature.

\subsection{SEM and EDS Analysis}

SEM (Scanning Electron Microscopy) was used to investigate the microstructure of samples fired at 1100 , 1200 and $1300^{\circ} \mathrm{C}$. A randomly collected sample fired commercially was taken for comparison purpose. Samples for SEM were etched with 5\% HF aqueous solution for various lengths of time, however, the resolution of microstructural features in samples etched for 3 minutes was good and were therefore, included in this thesis. Secondary electron imaging and $\mathrm{x}$-ray electron EDS was used for micro-structural and chemical analyses respectively.

\subsection{Samples Fired at $1100^{\circ} \mathrm{C}$ and Commercially Fired}

Micro-structural and elemental analyses were carried out using EDS and SEM. The compositions of sample fired at

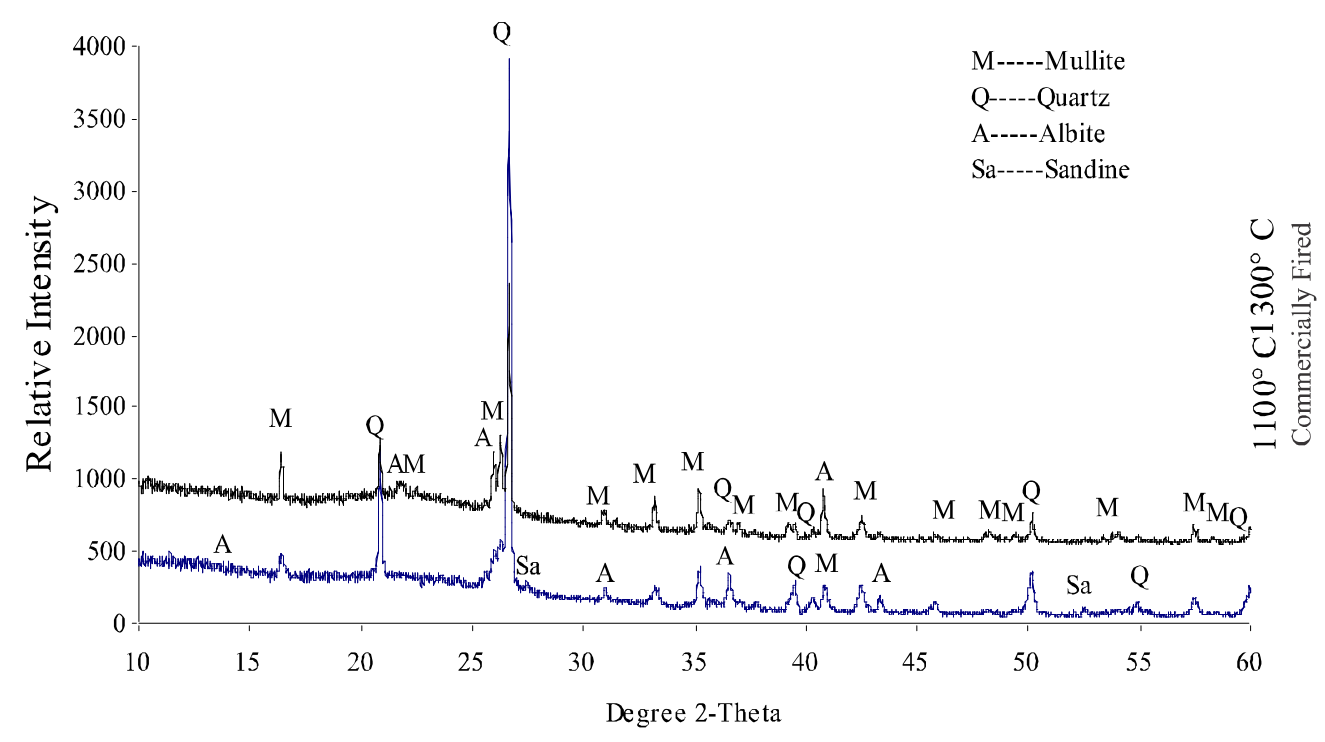

FIG. 2. XRD PATTERN OF SANITARY-WARE SAMPLES FIRED AT 1100 AND $1300^{\circ} \mathrm{C}$

Mehran University Research Journal of Engineering \& Technology, Volume 36, No. 3, July, 2017 [p-ISSN: 0254-7821, e-ISSN: 2413-7219] 
$1100^{\circ} \mathrm{C}$ and one fired commercially as confirmed by EDS are given in Tables 1-2.

The commercial sample provided by the local ceramic factory contained 7 Weight (\%) quartz, 27 Weight (\%) feldspar and 66 Weight (\%) clay [Sample provider, 2004].

Soda feldspar is used to lower the firing temperature (Iqbal

TABLE 1. OXIDES OF SAMPLE HEATED COMMERCIALLY

\begin{tabular}{|c|c|}
\hline Compounds & Weight (\%) \\
\hline $\mathrm{MgO}$ & 2.03 \\
\hline $\mathrm{Al}_{2} \mathrm{O}_{3}$ & 22.42 \\
\hline $\mathrm{SiO}_{2}$ & 42.47 \\
\hline $\mathrm{K}_{2} \mathrm{O}$ & 0.96 \\
\hline $\mathrm{TiO}_{2}$ & 0.97 \\
\hline $\mathrm{Fe}_{2} \mathrm{O}_{3}$ & 31.12 \\
\hline $\mathrm{Total}$ & 100.00 \\
\hline
\end{tabular}

TABLE 2. OXIDES OF SAMPLE HEATED AT $1100^{\circ} \mathrm{C}$

\begin{tabular}{|c|c|}
\hline Compounds & Weight (\%) \\
\hline $\mathrm{Na}_{2} \mathrm{O}$ & 2.06 \\
\hline $\mathrm{Al}_{2} \mathrm{O}_{3}$ & 22.41 \\
\hline $\mathrm{SiO}_{2}$ & 42.46 \\
\hline $\mathrm{K}_{2} \mathrm{O}$ & 0.965 \\
\hline $\mathrm{TiO}_{2}$ & 0.977 \\
\hline $\mathrm{Fe}_{2} \mathrm{O}_{3}$ & 31.11 \\
\hline $\mathrm{Total}$ & 100.00 \\
\hline
\end{tabular}

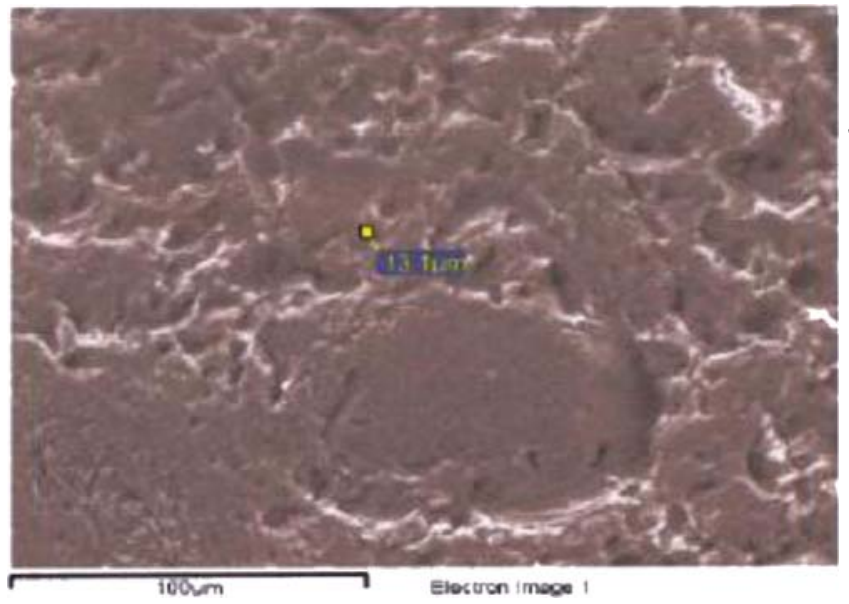

\begin{tabular}{c|c} 
Compounds & Weight\% \\
\hline $\mathrm{Na}_{2} \mathrm{O}$ & 3.7 \\
$\mathrm{Al}_{2} \mathrm{O}_{3}$ & 20.29 \\
$\mathrm{Si}_{2} \mathrm{O}_{3}$ & 73.75 \\
$\mathrm{~K}_{2} \mathrm{O}$ & 0.87 \\
$\mathrm{TiO}_{2}$ & 1.26 \\
$\mathrm{Total}$ & 100.00
\end{tabular}

FIG. 3. SECONDARY ELECTRON IMAGEFROM A GENERAL AREA OF THE SAMPLE FIRED AT 1100 ${ }^{\circ}$. AREA SCANNED OVER 13.1 $\mathrm{m}$ COMPRISES SILICA AND ALUMINA IN LARGE AMOUNT AND LESS AMOUNT OF SODIUM AND POTASSIUM WITH SOME IMPURITIES OF TITANIUM

Mehran University Research Journal of Engineering \& Technology, Volume 36, No. 3, July, 2017 [p-ISSN: 0254-7821, e-ISSN: 2413-7219] 
Regions containing Primary mullite of scaly appearance are shown in Fig. 5. This is consistent with previous studies performed at temperatures close to or at $1100^{\circ} \mathrm{C}$ ([Lee and Iqbal [6] Iqbal and Lee [10,13]). Scaly primary mullite forms in clay relicts at temperatures ranging from $1100-1200^{\circ} \mathrm{C}$ ([Lee and Iqbal [6]). As mentioned earlier, needles like large secondary mullite crystals are not expected to form at this temperature. Another reason for not observing the secondary mullite may be due to the short interval of firing time. Reasonable amount (31.11 Weight (\%)) of iron has also been detected by EDS (Fig. $5)$.

\subsection{Comparison of $\alpha$-Quartz and Mullite Grains}

Partial dissolution of $\alpha$-quartz begins at temperatures above $1200^{\circ} \mathrm{C}$, therefore, $\alpha$-quartz grain cannot be resolved from the matrix at low temperatures $\left(1100^{\circ} \mathrm{C}\right)$.
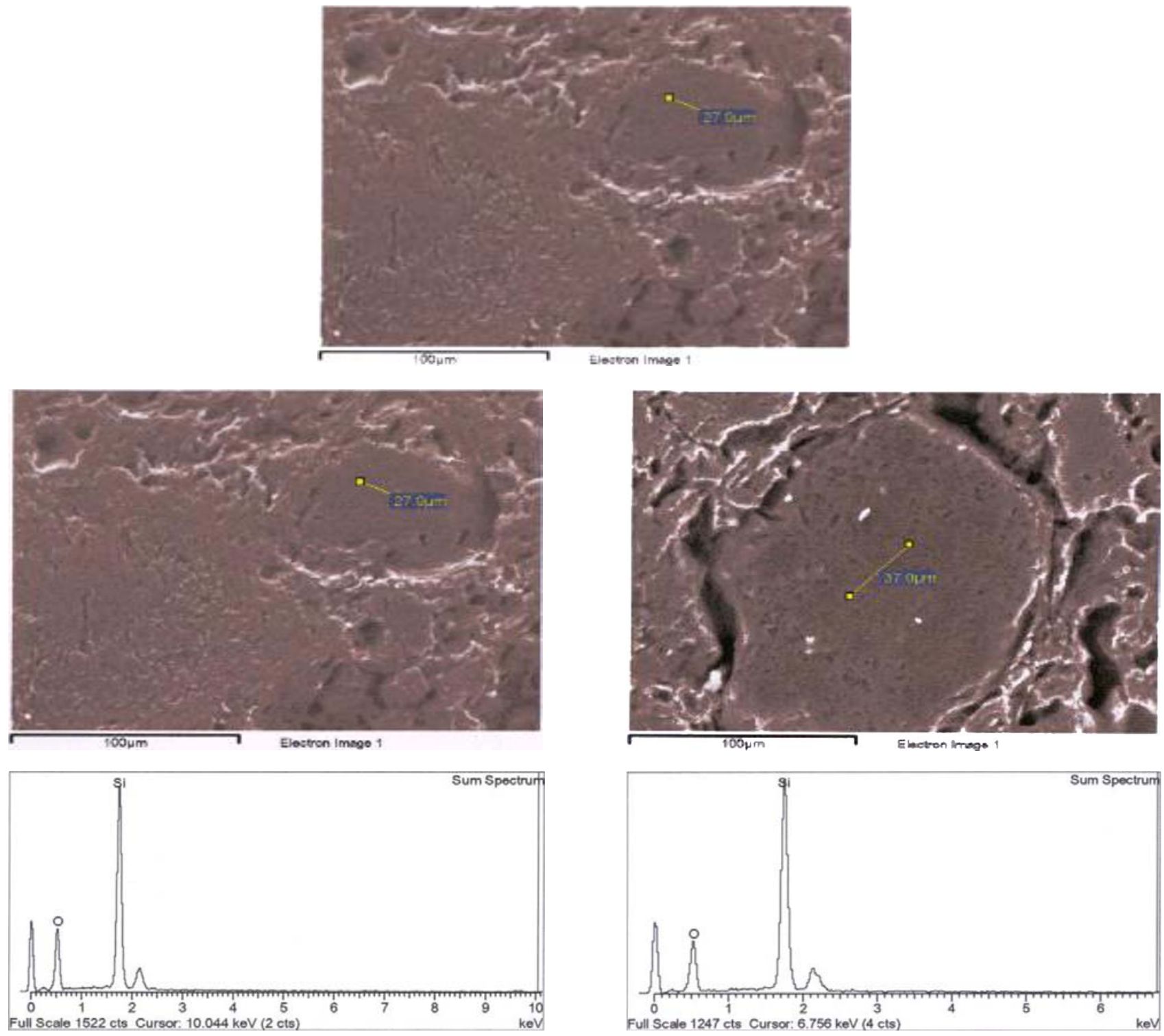

FIG. 4. AREAS SCANNED OVER 27.9 AND 37.0 Mm COMPRISES 100\% SILICAAS CONFIRMED BY IN SET EDS SPECTRA

Mehran University Research Journal of Engineering \& Technology, Volume 36, No. 3, July, 2017 [p-ISSN: 0254-7821, e-ISSN: 2413-7219] 
However, some large sharp-edged $\alpha$-quartz grains can be identified via EDS at $1100^{\circ} \mathrm{C}$ (Fig. 6). Corundum grains (Fig. 7) are located adjacent to clay or feldspar relicts, with no solution rim surrounding them. Therefore, at temperatures below $1200^{\circ} \mathrm{C}$, EDS is the only technique used in this study to confirm the identification of both quartz and corundum grains, however, at high temperatures $\left(>1200^{\circ} \mathrm{C}\right)$, the corundum grains have no
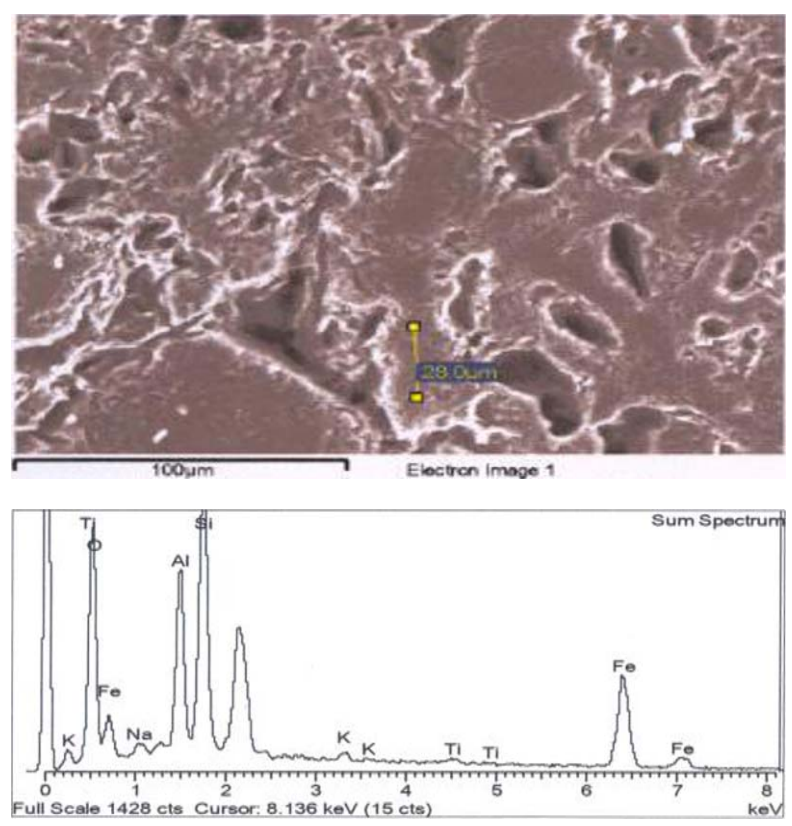

FIG. 5. SHOWS PRIMARY MULLITE OF SCALY APPEARANCE WITH REASONABLE AMOUNT OF IRON silica-rich solution rims around them and quartz grains have a silica-rich solution rim around them ([Iqbal and Lee [13]).

\subsection{Sample Heated At $1200^{\circ} \mathrm{C}$}

SEM-EDS results of the same samples reheated at $1200^{\circ} \mathrm{C}$ (Fig. 8 with marked EDS result) reveals the presence of silica rich matrix in the vicinity of $\alpha$-quartz grain "Q" along with some impurity elements as iron, titanium and potassium. Very little amount of sodium was detected probably due to small amount of feldspar used in the initial ingredients of the body. Traces of $\mathrm{Fe}, \mathrm{Ti}, \mathrm{Ca}$ and $\mathrm{K}$ were always present in the vicinity of $\alpha$-quartz grains. Primary mullite was observed as shown by "A, B, C" in Fig. 8(a). High clay relicts, lake of feldspar and improper mixing may be the possible reason for not observing secondary mullites in these samples, because secondary mullite forms in the regions in which flux particles were mixed well with clay or where flux has penetrated clay agglomerates ([Lee and Iqbal [6]). Secondary Mullite crystals originate from the clay relicts and grow into the feldspar relicts. Therefore less amount of feldspar used as body ingredient affect secondary mullite formation ([Iqbal and Lee [10]).

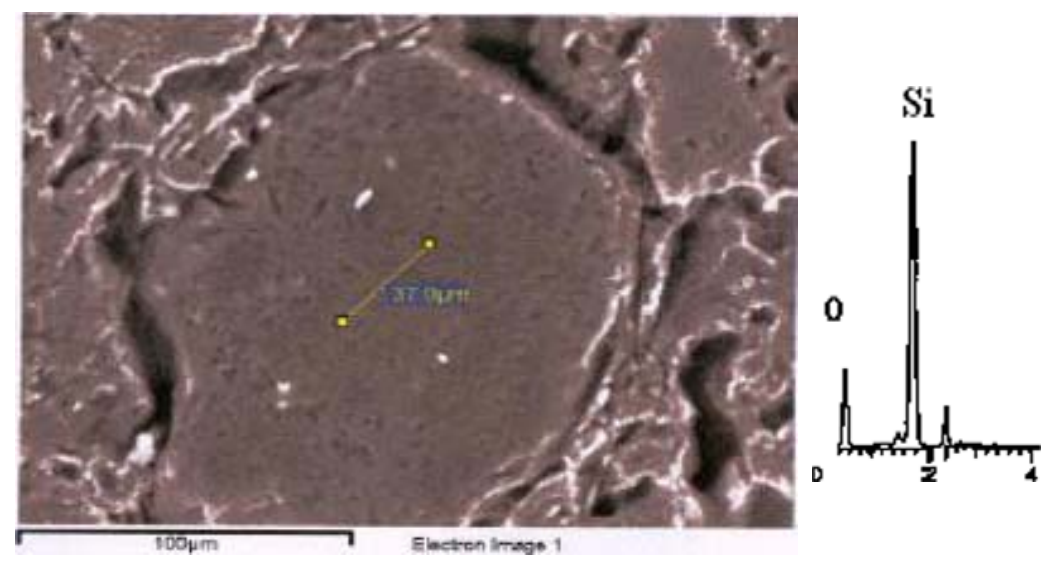

FIG. 6. AREA SCANNED OVER 37.0

Mehran University Research Journal of Engineering \& Technology, Volume 36, No. 3, July, 2017 [p-ISSN: 0254-7821, e-ISSN: 2413-7219] 
Glaze composition and morphology is shown in Fig. 9. EDS revealed the presence of Barium, Zinc and Zirconium as glaze pigments added to clay for coating the surface of the sanitary ware. A trace amount of
Titanium was also detected in the glaze. Note the absence of $\mathrm{Fe}$ in the glaze composition that may have been carefully removed as it may affect the white colour of the sanitary-ware product.
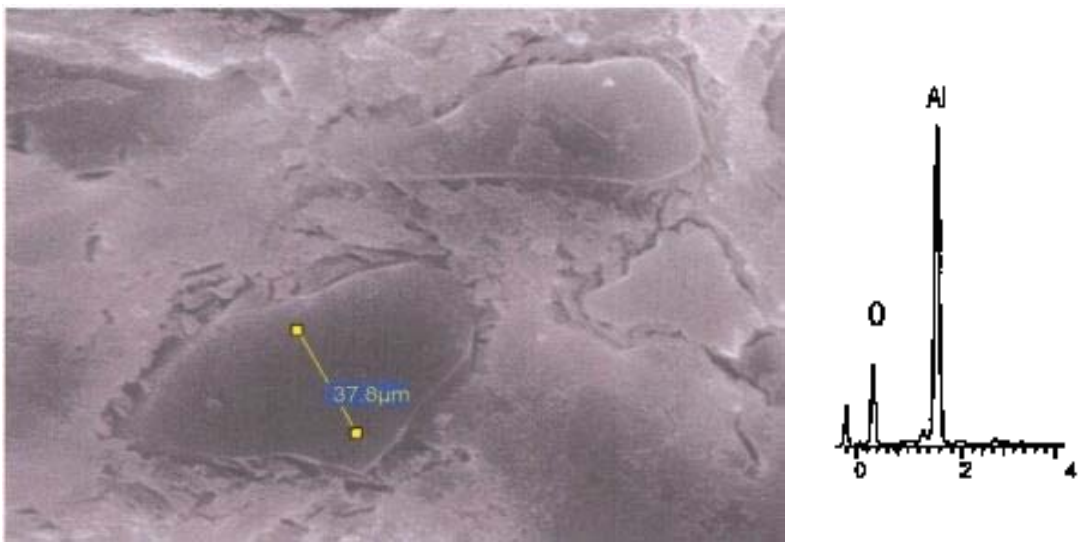

FIG. 7 .REGION SCANNED OVER 37.8 MT IS PURELY ALUMINA, INSET EDS CONFIRMS THE CORUNDUM GRAIN

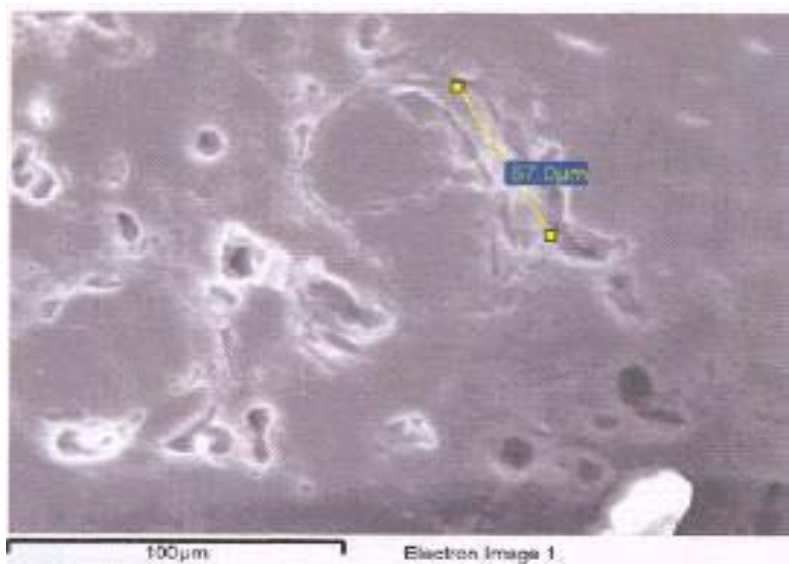

\begin{tabular}{c|c} 
Compounds & Weight\% \\
\hline $\mathrm{Na}_{2} \mathrm{O}$ & 282 \\
$\mathrm{Al}_{2} \mathrm{O}_{3}$ & 21.27 \\
$\mathrm{SiO}_{2}$ & 71.88 \\
$\mathrm{~K}_{2} \mathrm{O}$ & 1.08 \\
$\mathrm{TiO}_{2}$ & 1.32 \\
$\mathrm{Fe}_{2} \mathrm{O}_{3}$ & 1.62 \\
$\mathrm{Total}$ & 100.00
\end{tabular}

FIG. 8. SEI OF SAMPLE REHEATED AT $1200^{\circ} \mathrm{C}$. THE EDS OF THE MARKED REGION REVEALS THE PRESENCE OF SILICA RICH MATRIX IN THE VICINITY OF $\alpha$-QUARTZ GRAIN “ $Q$ ” ALONG WITH OTHER IMPURITIES SUCH AS IRON, TITANIUM POTASSIUM. LABELS A, B AND C SHOW PRIMARY MULLITES

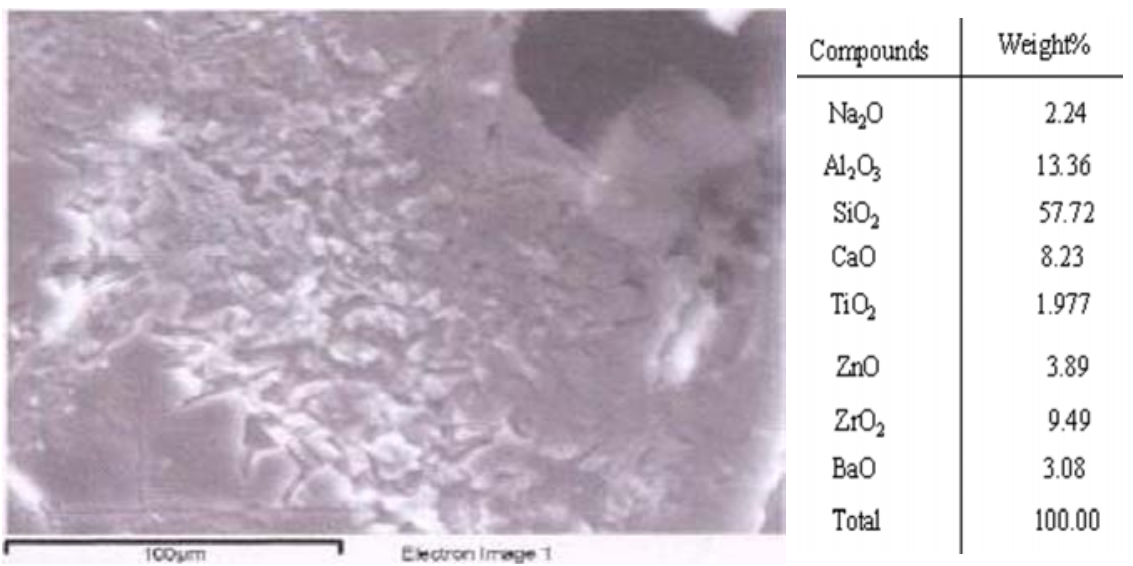

FIG. 9. GLAZE COMPOSITION AND MORPHOLOGY OF THE SAMPLE FIRED AT $1200^{\circ} \mathrm{C}$

Mehran University Research Journal of Engineering \& Technology, Volume 36, No. 3, July, 2017 [p-ISSN: 0254-7821, e-ISSN: 2413-7219] 


\subsection{Sample Fired at $1300^{\circ} \mathrm{C}$}

The microstructure of sample reheated at $1300^{\circ} \mathrm{C}$ contains elongated needles of secondary mullite (Fig. 10). The high quantity of iron oxide detected (Fig. 10) in these needles makes the precise analysis ambiguous. Crystals of similar morphology observed at temperatures above $1200^{\circ} \mathrm{C}$ in others studies of vitreous ceramics using pure raw materials are identified as secondary mullite ([Lee and Iqbal $[6,13])$. The presence of iron oxide may be due to the iron-rich glass covering the crystals. The presence of other elements tabulated in (Fig. 10) also indicates that the SEM probe used for chemical is not precise enough to isolate the crystal from the glassy matrix and peaks due to other elements in the vicinity overlap the peaks from the marked region (Fig. 10).

Fig. 11 shows the denteric growth of mullite in a region, where $50 \% \mathrm{SiO}_{2}$ exists (Table 3). Sodium feldspar conferring the fluidity upon the matrix is generally believed to allow faster mulllite growth than other alkali silicates. In our study, the amount of $\mathrm{Na}$ detected in the vicinity of crystal is low enough to enhance mullite growth to the observed size ([Schuller [12] and Kobayashi et. al. [28]). In vitreous ceramics, the mixing of raw materials is always incomplete and the composition changes from region to region which may be the possible reason for enhanced growth rate of mullite in one region and depressed growth rate in the other.

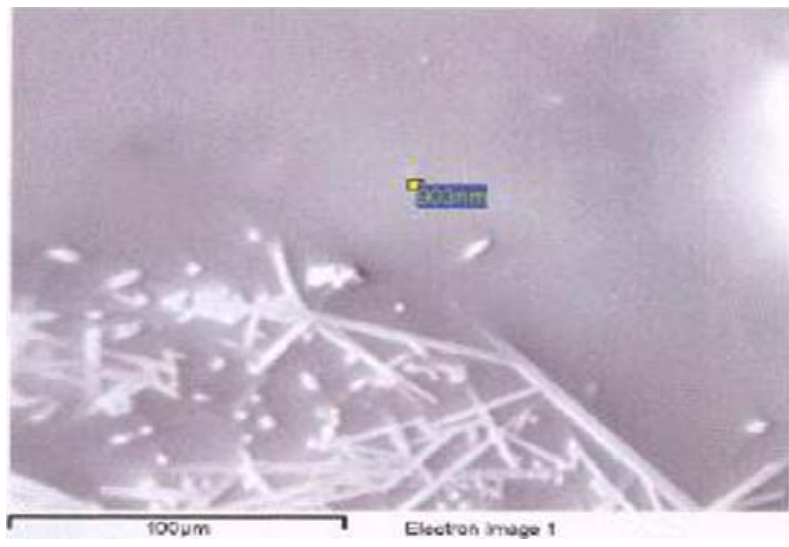

FIG. 11. DENTERIC GROWTH OF MULLITE IN SILICA REGION

TABLE 4. OXIDES OF SAMPLE HEATED AT $1300^{\circ} \mathrm{C}$

\begin{tabular}{|c|c|}
\hline Compounds & Weight (\%) \\
\hline $\mathrm{Na}_{2} \mathrm{O}$ & 5.02 \\
\hline $\mathrm{Al}_{2} \mathrm{O}_{3}$ & 14.87 \\
\hline $\mathrm{SiO}_{2}$ & 50.38 \\
\hline $\mathrm{K}_{2} \mathrm{O}$ & 0.55 \\
\hline $\mathrm{CaO}$ & 1.20 \\
\hline $\mathrm{TiO}_{2}$ & 2.26 \\
\hline $\mathrm{Fe}_{2} \mathrm{O}_{3}$ & 9.95 \\
\hline
\end{tabular}

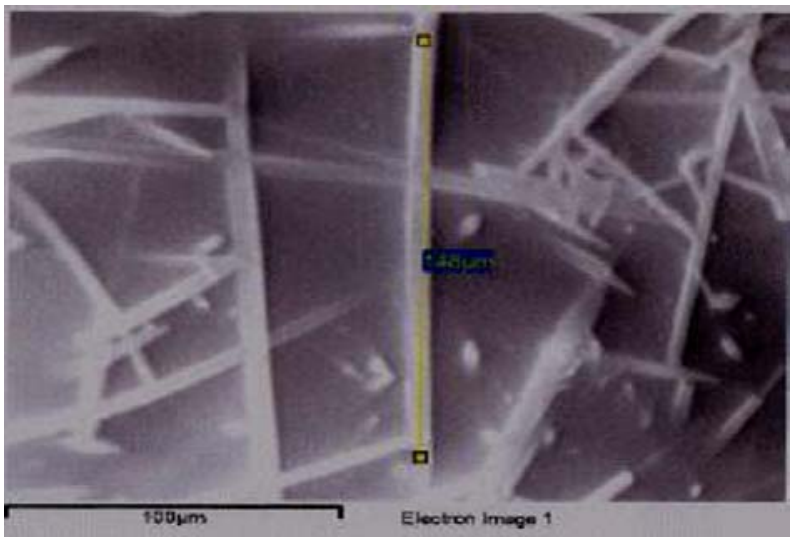

\begin{tabular}{c|c} 
Compounds & Weight\% \\
\hline $\mathrm{Na}_{2} \mathrm{O}$ & 3.1 \\
$\mathrm{MgO}$ & 0.85 \\
$\mathrm{Al}_{2} \mathrm{O}_{3}$ & 16.837 \\
$\mathrm{SiO}_{2}$ & 54.68 \\
$\mathrm{~K}_{2} \mathrm{O}$ & 0.90 \\
$\mathrm{CaO}$ & 1.20 \\
$\mathrm{TiO}_{2}$ & 2.55 \\
$\mathrm{Fe}_{2} \mathrm{O}_{3}$ & 15.64 \\
$\mathrm{ZnO}$ & 4.16 \\
$\mathrm{Total}$ & 100.00
\end{tabular}

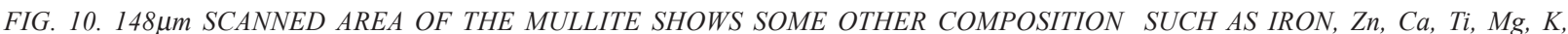
WHICH CONTRADICTS THE COMPOSITION (3 $\left.\mathrm{Al}_{2}: 2 \mathrm{SiO}_{2}\right)$ OF MULLITE

Mehran University Research Journal of Engineering \& Technology, Volume 36, No. 3, July, 2017 [p-ISSN: 0254-7821, e-ISSN: 2413-7219] 


\section{CONCLUSIONS}

(i) XRD revealed the presence of $\alpha$-quartz and mullite as major crystalline phases in all the sanitary ware samples fired at 1100 and $1300^{\circ} \mathrm{C}$. A small number of low intensity XRD peaks were also present which could be due to albite and sanidine, however, their peak intensities decreased with increase in temperature.

(ii) Consistent with our XRD analysis, SEM also revealed the presence of Mullite and $\alpha$-quartz in the investigated samples.

(iii) Consistent with previous studies, SEM revealed the presence of two types of mullite in the investigated samples. Only Primary mullite was present in samples fired at $1100^{\circ} \mathrm{C}$, and both primary and secondary mullite were present in samples fired at 1200 and $1300^{\circ} \mathrm{C}$.

(iv) One of the samples also contained corundum grains but the absence of XRD peaks due to corundum from the relevant spectra reveal that the percentage of corundum added was too low to be detected with XRD.

The level of impurities such as titanium and iron in the raw materials used was much higher than those used in the previous studies.

\section{ACKNOWLEDGEMENT}

It is difficult to acknowledge fully those who directly or indirectly have influenced me either by personal contacts, in lectures, in the laboratory or by their written work. It will be apparent from the cited works within the text that we are indebted to many such people.

\section{REFERENCES}

Graham, S., "Trends for Material Suppliers", Asian Ceramics, pp. 12-23, July, 1998.
[2] Klein, A.A., "Constitution and Microstructure of Porcelain", National Bureau of Standards \& Technological Paper, Volume 80, pp. 3-38, 1916-1917.

[3] Weymouth, J.H., and Williamson, W.O., "Some Observation on the Micro-structure of Fired Earthenware", Transaction of British Ceramic Society, Volume 52, pp. 311-328, 1953.

[4] Jackson, G., "Sanitary Ware", Journal of British Ceramic Society, Volume 5, pp. 128-134, 1968.

[5] Cole, W.F., "Moisture Expansion", Aspects of Early Australian Experience, Transaction \& Journal of British Ceramic Society, Volume 82, 1983.

[6] Lee, W.E. and Iqbal, Y., "Influence of Mixing on Mullite Formation in Porcelain", Journal of European Ceramic Society, Volume 21,No. 14, pp. 2583-2586, 2001.

[7] Manfredini, T., and Pellacani, G.C.,"Engineering Materials Hand Book Ceramics and Glasses", Tile White Ware, Volume 4, pp. 925-42, Department of Chemistry, University of Modena, Italy, 1991.

[8] McConville, C.J., Lee, W.E., and Sharp, J.H., "Microstructural Evolution in Fired Kaolinite", Transactionon British Ceramic, Volume 4, pp. $162-68,1998$.

[9] Guanzhou, Q., Jiang, T., Li, G., Fan, X., and Huang, Z., "Activation and Removal of Silicon in Kaolinite by Thermo-Chemical Process", Journal of Metallurgy, Volume 33, pp. 121-128, Scandinavian, 2004.

[10] Iqbal, Y. and Lee, W.E., "Fired Porcelain Micro-Structures Revisited", Journal of American Ceramic Society, Volume 82, No. 12, pp. 3584-90, 1999.

[11] Schramm, E., and Hall, F.P., "The Fluxing Effect of Feldspar in White Ware Bodies", Journal of American Ceramic Society, pp. 159-168, 1936.

[12] Schuller, K.H., "Reaction between Mullite and Glassy Phase in Porcelain", Transaction of British Ceramic Society, Volume 63, No. 2, pp. 103-17, 1964. 
[13] Iqbal, Y.,and Lee, W.E., "Micro-Structural Evolution in Tri-Axial Porcelain”, Journal of American Ceramic Society, Volume 83, No. 12, pp. 3121-3127, 2000.

[14] Morey, G.W., and Bowen, N.L., "The System KAlSi ${ }_{2} \mathrm{O}_{6}$, Journal ofAmerican Ceramic Society, Volume 5, pp. $1-21,1922$.

[15] Maiti, K.N., and Kumar, S., "Microstructure and Properties of a New Porcelain Composition Containing Crystallizing Glasses as Replacement for Feldspar", Transaction on British Ceramic, Volume 91, pp. 19-24, 1992.

[16] Kobayshi, Y., Ohira, O., Ohasahi, Y., and Kato, A., "Effact of Glaze on Bending Strength of High Strength White-Ware Bodies", Journal of Japan Ceramic Society, Volume 5, No. 98, pp. 504-509,1990.

[17] Palmonari, C., Esposito, L., Tucci, A., and Timellini, G., "Short Fiber Reinforced Ceramic Tiles", Silicate Industries, pp. 3-4,1996.

[18] Youssef, N.F., Abadir, M.F., and Shater, M.A.O. "Utilization of Soda Glass (Cullet) in the Manufacture of Wall and Floor Tiles", Journal ofEuropean Ceramic Society, Volume 18, pp. 1721-1727, 1998.

[19] Vaughan, F., and Dinsdale, A., "Moisture Expansion", Transaction of British Ceramic Society, Volume 6, pp.1-62.

[20] Sallam, E.M.M., Messer, P.F., and Ford, W.F., "Equilibrium Constitution as an Index of the Verification of Tri-Axial White Wares", Transaction and Journal of British Ceramic Society, Volume 75, 1976.
[21] Lundin, S.T., "Microstructure of Porcelain, Microstructure of Ceramic Materials", Proceedings of American Ceramic Society Symposium, National Bureau of Standards Miscellaneous Publications No. 257, National Bureau of Standards, MD, pp. 93-106, Gaithersburg, 1964.

[22] Knudsen, F.P., Journal of American Ceramic Society, Volume 42, No. 8, pp. 376, 1959.

[23] Dinsdale A., and Wilkinson, W.T., "Strength of White Ware Bodies", Journal of British Ceramic Society, Volume 6, June, 1966.

[24] Bradi, R.C., "A High Tech Approach to a Traditional Ceramic- The Toughness of Porcelain", Proceedings of International Symposium on fire Ceramics, Volume 86, pp. 17-22, Arita, 1986.

[25] Mackenzie, W.S., and Smith, J.V., "The Alkali Feldspar: 111 An Optical and X-Ray Study of High Temperature Feldspar”, American Mineral, Volume 41, Nos. 5-6, pp. $405-427,1956$

[26] McConvile, C.J., "Related Microstructural Development on Firing Kaolinite, Illite and Smectite Clays", Thesis, Department of Engineering Materials, University of Sheffield, 1999.

[27] Kobyashi, Y., Ohira, O., Ohashi, Y., and Kato, E., "Effect of Firing Temperature on Bending Strength of Porcelain for Table Ware", Journal of America Ceramic Society, Volume 75, No. 7,pp.1801-1806, 1992.

[28] Kobayashi, Y., Ohira, O., Ohashi, Y., and Kato, E., "Verification of White Ware Bodies in Alumina, Feldspar, Kaolin System”, Journal of Japan Ceramic Society, Volume 100, No. 5,pp.743-749, 1992.

[29] Durr Ceramics Factory, Industrial Estate Hayat Abad Peshawar 